\title{
IS POLICY OF MEMORY POSSIBLE AND HOW?
}

\author{
Wioletta Małgorzata Kowalska \\ University of Białystok, Institute of Sociology, \\ Plac Uniwersytecki 1, 15-420 Białystok, Poland \\ E-mail:koma@uni.torun.pl
}

\begin{abstract}
The purpose of this paper is to discuss the concept and possibility of the democratic policy of collective memory in national and trans-national, or European, contexts. The presupposition of the paper is that memory, while largely unintentional, is also intentional and even partially constructed and, as such, always subjected to influences, even manipulations, i.e. to different policies. Memory is no doubt a "political question" and every policy deals with it, trying to shape social memory according to some political and ideological objectives. In particular, communism implied a very strong policy of memory aiming at destroying many sorts and layers of memory in favour of another. After the fall of communism there have also been many attempts at reshaping collective memory. These recent attempts have been certainly much more democratic than the communist manipulations but far from being based on the democratic principle of equality of different perspectives and discussion. The attempt was rather, namely in Poland, to replace, once again, one kind of "official” memory by another. The really democratic policy of collective memory should imply, on the contrary, a free confrontation of different and sometimes opposing memories in the open public sphere where no "symbolic violence" has place and where all participants not only treat each other as equals but are also ready to modify the meaning of their particular memory and look for mutual comprehension, if not for agreement. The question is whether such democratic policy can ever be more than a moral postulation.
\end{abstract}

Keywords: consensus/dissensus, democracy, memory, policy, power, symbolic violence, universalism/relativism.

DOI: $10.3846 / 2029-0187.2008 .1 .15-21$

The paraphrase of the Kantian question, constituting the title of this text, leaves the fundamental problem open, but implies a solution of some preliminary questions.

First of all, it presumes that there is always, and inevitably, a policy of memory. This presumption seems obvious. In case politics means activity aiming at organising collective life through relations of power in a broad sense, including symbolic power, the result of which - but also, to some extent, the basis is the common identity of individuals, and if what decides such an identity is mainly memory, then a policy of memory is a necessary dimension of any politics. Every policy not only has to concern memory, first of all the so-called collective memory, but also to aim at shaping it in a way accordingly to the purposes and ideology adopted.

Different political purposes require different memories. The fight for independence or renouncement to a part of sovereignty, construction of a mono- or multi-national state, 
communism and capitalism, revolution and restoration look for their legitimisation in different memories. The connection between a concrete policy and a concrete sort of memory is certainly not simple, not linear, rather circular or "dialectical": a certain policy emerges from a certain kind of memory and, vice versa, a certain memory results from a certain policy. What is important for us is that politics not only relies on memory, but also influences, controls and shapes it. After reaching a sufficient intensity and self-conscience this influencing turns into manipulation, the main examples of which remain the fascist and communist propaganda that tended to the complete elimination of certain sorts or dimensions of memory and of their very plurality - on behalf of monolithic collective memory of a defined type.

Secondly, our title question presumes that the policy of memory, known from ancient and recent history, has, as a rule, a non-democratic character - even in the so-called democratic countries. That means, to put it briefly, that the shaping of collective memory which would be able to legitimise a given political order is never free from violence, at least symbolical. Or, that collective memory of members of a political community never represents either a simple sum of spontaneous individual and local memories, or the result of an open communication between them, based on the principle of equality of every party, but is always subjected to a pressure and repression from dominant groups or from the power in a broad sense. In other words, the collective memory or, at least, what can be called a public or official collective memory, emerges as the result of re-construction and structurization of the diverse "magma" of individual and local memories by the mechanisms of political and ideological constraints.

The susceptibility of memory to such influence - such manipulation - is relative and beyond question. We have to draw such a conclusion from our intuitive and reflexive knowledge about the mechanisms of memory, a knowledge that we can develop in a whole phenomenology of memory like that of Paul Ricoeur (see his La memoire, l'histoire, l'oubli, 2000). But no savant investigation is necessary to admit that memory is partly unintentional and even unconscious, and partly intentional; partly closed and partly open or depending on the whole psychic and social context; partly "dogmatic" and partly "hypothetic" or susceptible to different interpretations. What, in memory, is intentional, then open and "negotiable”, but also "manipulable” impressionable, prone to external influences, is, especially, the global meaning of particular memories, of memorised (or taught, transmitted by others) contents. Policy shapes, then, this global meaning. Incapable of creating the data of memory, it aims, at least, at organising them in a way, selecting and hierarchising. It attempts to decide what is worth being memorised and what is not, and what use we should make of what we remember, replacing our memories in an appropriate context. But the politico-ideological constraints act also on the unconscious mechanisms of memory, leading to the "useful" suppressions, transfers, rationalisations, sublimations etc. In a word, it leads to re-working the memory contents not only at the level of global meaning, but also at the level of concrete particular contents or experiences.

In extreme cases, the political shaping of memory can result in a total suppression of the spontaneous private memory everywhere the latter is related to the functioning 
of the political community. More often, or usually, it leads to a split, more or less distinct, between, on the one hand, the public or "official", and, on the other hand, the private or "unofficial" memory. What is at stake here is not only the inevitable difference of range between the biographical, individual and familial memory, which is both relatively detailed and partial or perspective, and a "common" memory which is rather schematic and which results more from education than from personal experience. And it is not only a difference of intensity, or quality, between these two kinds of memory, one of which, the biographical, belongs to the order of real-life in a proper sense that fulfil the intention of recollection, while the other, "common”, consists mainly of signs, assimilated information and schematic pictures which do not correspond, as a rule, to any "sensible intuition". What is at stake here is also and mainly the fact that the meaning the individual gives to his/her memories in the private sphere is often different from the one he/she gives in the public order. Some trivial examples: a person recollects communism or the time when Vilnius or Grodno belonged to Poland quite fondly, but in the public sphere, which is governed by a certain norm of memory, he/she either does not reveal his/her memories, or subjects them to different critical adjustments. These adjustments do not necessary testify to hypocrisy or conformism, they can result from an authentic criticism of the importance of his/her own experience, from a reflexive relativization of his/her own memory in front of the memory of others. Yet, it is beyond question that there is a strict correlation between the tendency to conceal or to correct the meaning of our own memory and the level of pressure put on the personal, biographical memory by the current policy and its norm of collective memory. Also, it seems obvious that the more powerful and centralised, so, the less democratic, is this pressure, the grater becomes the split between the biographical memories and "public memory", and the grater the level of a simple conformism rather than critical reflexivity.

After these preliminary remarks, we need to explain the very concept of "democratic policy of memory”. When, i.e. under what conditions, does a policy of memory deserve to be called democratic?

The quality of democracy is certainly gradable. Between the ideal democracy and the lack of democracy there is a whole spectrum of possibilities. The actual policy of memory realised in countries such as Poland, since the turn of 1989, can be classified as "moderately democratic". It is still worth noting that in the period of 2005-2007, under the government of the national conservatives from "Prawo i Sprawiedliwość" (Law and Justice), policy in general, and policy of memory in particular, approached the authoritarian pole. It is manifest in the special programme of "historical policy", promoted and enforced by the government of Kaczynski, which reflects the ambition of shaping the common memory through the undertakings such as broad "lustration" and "de-communisation", the particularly solemn celebration of certain historical events (like the Warsaw Insurrection, all revolts against the communist power, the birth of "Solidarność", etc.) and the omission or reduction of others. It was called a "moral revolution". In fact, it is also, and mainly, a revolution in the domain of the official collective memory, or, at least, a decisive correction within it, or within the national identity. 
More distinctly than ever after 1989, some kinds of private and local memories were and are disqualified and put beyond the limits of the recognisable collective memory. That concerns not only the complex memory of communism, but also that of the first fifteen years of transition (the so-called Third Republic presented by Kaczynski's team as deeply unjust and corrupted). It concerns also, and primarily, the memories of different minorities (ethnic, religious, political, sexual) which cannot have place in the project of the monolithic memory of "Pole-Catholic-anticommunist", ever fighting for the independence of homeland, ever faithful to the ancient tradition and to the Roman Church, and obligatory heterosexual.

Neither Polish, nor any other actual policies of memory constitute our main interest here. Let us make do with the general statement that the policy of memory carried out in today's Poland, as in many other ex-communist countries, too often represents only a direct negation of the communist policy. Although it is surely less authoritarian than the latter and, in principle, not connected with the use of simple, physical violence, it still remains - precisely as negation - dependent on the communist policy. Too often, it simply reverses vectors on promoting the memory which was repressed under communism and vice versa, and conserving the ideal of unity that marginalises and suppresses any minority memory, incommensurate with the required norm.

In order to measure the distance between any real policy of memory and its democratic ideal, we need, therefore, formulate this ideal. In a first approximation, the question seems, at least theoretically, quite simple. If we admit that democratic policy of memory ought to fulfil the general criteria of democracy and that, among such criteria, the most important are the principle of equal treatment and the right to equal contribution, related to the principle of freedom understood both as freedom from constraint and as freedom to self-determination, then we should conclude that the democratic policy of memory is the one which renders possible a really open public space where everyone can reveal his/her memories and where the common memory is only a changeable configuration of different individual and local memories, or, better, a subject of constant discussion. Such a discussion should be free from violence, even only symbolical, which means that different points of view - different local memories - should be treated as having equal rights to be publicly articulated and taken into account as "moments" of the common memory. In this way, the ideal democratic policy of memory would suppress the shift between private and public memory and would make the latter really egalitarian and pluralistic.

There are, however, two modalities of this ideal: the relativistic and the universalistic. According to the first (which can also be called “post-modern”), not only any kind of local memory is worth as much as any other, but there exists an insurmountable conflict between different perspectives and memories (see Jean-Francois Lyotard, his Condition post-moderne (1979) and Différend (1981)). Democratic policy of memory would then be a policy of permanent disagreement (“dissensus”). The unpleasant consequence of such position, inevitable, even though probably undesired by the main spokesmen of "post-modernism”, is the recognition of equality between memories of victims and butchers, occupants and combatants for freedom, exploited and exploiters. 
According to the other option, on the contrary, not every kind of memory is equally worth being expressed, promoted and taken into account in the public sphere. Those are only worth of it which can be universalised, i.e. which are susceptible to be recognised by many others. The question of memory and, more specifically, of collective memory is related, therefore, to the question of common democratic values, properly understood. The democratic equality properly understood is not an equality of victim and butcher, oppressed and oppressor, but such a moral relation between individuals which excludes the function of butcher and oppressor. And the democratic freedom is not a freedom to do and tell anyone one's own wishes but to express and develop oneself in front of others and with regard to their rights.

However, the real history is that of conflicts and suffering. This is why the democratic policy of memory has to deal with the question of who and why should be conceived as a victim, and who and why as butcher. In the universalistic perspective, it is the very identification of butchers and victims that should be put to democratic debate. And the most desirable, if not the most probable, result of such a debate would be the recognition that, except for some extreme cases, different parties of historical conflicts were both or alternatively butchers and victims, oppressors and oppressed. In other terms, the result and, partly, the very presupposition of democratic policy of memory would be the assumption that history is never black and white, rather grey or, better, multi-colored, that national, ethnic, religious and political divisions do not correspond to moral distinctions and that the great majority of historical actors are neither devils, nor saints, but sinful and limited human beings.

Although the recognition of that can seem banal, it is very difficult in practice. It requires, from all participants of the democratic debate, the readiness to subject their own ideas and interpretations of the past to revisions and critical correction. It requires the capacity to transcend one's own perspective, to understand the perspective of others and to share, at least partially, their reasons. There is no other way of reaching the level of universality, indeed, than in recognizing one's own limits and in opening oneself to other points of view and other memories. But this is a never ending process. Universality is, by definition, a purely ideal horizon: never really reached, it always remains a task which requires from anyone permanent criticism and self-reflection, permanent openness to re-interpret, re-negotiate the global meaning of one's memory.

I think that the second, universalistic, model of democratic policy of memory is the good one. To put it symbolically, I believe it is J. Habermas (1984-1987) with his concept of "communicative action" and of a possible consensus, and not Lyotard with his idea of "dissensus", that is right. I am convinced that democracy and democratic policy of memory are not possible without the ideal horizon of common values and norms. While never reached, this horizon should be postulated and constantly negotiated through the effort of mutual understanding. But I am also perfectly aware that the democratic policy of memory in this sense can be only a moral postulation, not a political fact. It demands too much from the participants of public debate and from the very nature of this debate. It demands indeed that the confrontation of different local perspectives becomes a kind of common psychoanalysis and psychotherapy, thanks 
to which individuals overcome and go beyond their idiosyncrasies towards others and look for what is common or universal. From this point of view, the really democratic state would be the one which ensures the conditions to such a collective psychoanalysis and psychotherapy. This is certainly a utopian idea. The actual state, even formally democratic, i.e. provided with necessary democratic institutions, always implies the relations of power and constraint, also and mainly in the sphere of symbols. Nevertheless, the idea of democratic policy of memory is worth being formulated and promoted as the "regulating idea” of real democracies. Without such idea, democracy can easily turn either into camouflaged authoritarianism, or into anarchy.

\section{Conclusions}

The ideal horizon of democratic policy is particularly important in the European context, given the need for creating a common European identity and memory. This identity and memory cannot be a mere sum or a simple confrontation of schematic national memories. The European identity, based on the commonly negotiated interpretation of different European experiences of the past, can and should become a common denominator for many local memories. It can and should become what unifies both different nations and different groups within one Nation-State. To set such a common European identity and memory, we have to introduce many critical corrections into our local memories. And it is important that these corrections were not imposed in an authoritarian way, or from a European centre, but that they occur thanks to and within an authentic democratic debate, carried on by as many participants in every European country as possible.

\section{References}

Habermas, J. 1989. The Structural Transformations of the Public Sphere. Cambridge: The MIT Press.

Habermas, J. 1984-1987. The Theory of Communicative Action, vol. 1-2. Cambridge: Polity.

Lyotard, J.-F. 1979. La condition postmoderne. Rapport sur le savoir. Paris: Minuit.

Lyotard, J.-F. 1981. Différend. Paris: Minuit.

Ricoeur, P. 2000. La mémoire, l'histoire, l'oubli. Paris: Editions du Seuil. 


\title{
AR IMANOMA ATMINTIES POLITIKA IR KAIP?
}

\author{
Wioletta Małgorzata Kowalska
}

\begin{abstract}
Santrauka
Aptariamas demokratinès politikos ir kolektyvinès atminties santykis bei jo galimybės sąlygos nacionaliniame ir transnacionaliniame (europiniame) kontekste. Teigiama, kad nesąmoninga atmintis neišvengiamai priklausoma nuo tam tikru itakų ir net manipuliacijų, t. y. nuo skirtingų politinių pažiūrų. Atmintis neabejotinai esanti tam tikras „politinis klausimas“, ị kurị skirtingų politinių pažiūru atstovai bando skirtingai atsakyti, bandydami socialinę atmintį apibrezžti, vedini savųju politinių ir ideologinių tikslų. Komunizmo išpažinèjai siekè sunaikinti kolektyvinę atmintị, siekdami ịvairios politinès naudos. Žlugus komunizmui buvo stengiamasi iš esmès atgaivinti kolektyvinès atminties fenomeną. Šiandienės pastangos tai padaryti esančios kur kas demokratiškesnės negu komunistų vykdytos manipuliacijos, tačiau vargu ar pagrịstos skirtingu politinių pažiūrų lygiavertiškumo ir demokratijos principais. Demokratinè politika turètų užtikrinti laisvą skirtingų, o kartais net ir prieštaraujančių tarpusavyje atminties rūšiu koegzistavimą viešosiose srityse, kuriose nebūtu jokių „simbolinės prievartos“ apraiškų, o visi visuomenès nariai turètų lygias pilietines teises siekdami abipusio supratimo ir tarpusavio sutarimo. Pasak autorès, net šiandien tenka kelti klausimą - ar demokratinè politika gali pretenduoti į aukštesnị nei moralinio postulato statusą?
\end{abstract}

Reikšminiai žodžiai: konsensas, disensas, demokratija, atmintis, politika, valdžia, simbolinè prievarta, universalizmas, reliatyvizmas. 